\title{
The Relationship between Humanness and Knowledge Sharing in Malaysia Empirical Evidence from Malaysian Managers
}

\author{
Ilona H. Boom \\ Faculty of Economics and Business, University of Groningen \\ Bartjan W. Pennink \\ Faculty of Economics and Business, University of Groningen
}

\begin{abstract}
This paper explores whether there is a relationship between humanness and the willingness to share knowledge in Malaysia. Furthermore, the differences between the Malay, Chinese and Indian ethnicities are researched for the presence of humanness and the willingness to share knowledge. Two hundred and fourteen respondents from privately owned companies participated in this research showing that there is a strong relationship between humanness and knowledge sharing. However, the differences between the three ethnicities are small, which is a surprising finding. It can be concluded that people-oriented managers (one of the ways to express humanness) are more willing to share knowledge, and differences between ethnicities have no influence in this matter. From these results, it can be recommended to managers and organizations in Malaysia that they pay more attention and be aware of their management style.Stressing the humanness aspects more as they are described could improve the knowledge transfer within companies.
\end{abstract}

\begin{abstract}
Abstrak: Artikel ini bertujuan untuk melihat apakah ada hubungan antara kemanusiaan dan keinginan untuk saling berbagi pengetahuan di Malaysia. Penelitian ini juga meneliti perbedaan antara etnis Melayu, Tionghoa, dan India untuk mengetahui keberadaan kemanusiaan dan kemauan dalam berbagi pengetahuan. Dua ratus empat belas responden dari perusahaan swasta yang berpartisipasi dalam penelitian ini menunjukkan bahwa ada hubungan yang kuat antara kemanusiaan dan berbagi pengetahuan. Namun, ada temuan yang mengejutkan bahwa perbedaan diantara tiga etnis tersebut kecil. Hal ini dapat disimpulkan bahwa seorang manajer yang peduli dengan anak buah (people-oriented managers) lebih bersedia untuk berbagi pengetahuan, dan perbedaan antar etnis tidak memiliki pengaruh dalam hal ini. Dari hasil penelitian, dapat dikatakan bahwa manajer dan organisasi di Malaysia lebih memperhatikan dan menyadari tipe atau gaya manajemen mereka. Penekanan yang lebih pada aspek kemanusiaan seperti yang telah digambarkan dapat meningkatkan transfer pengetahuan (knowledge transfer) dalam perusahaan.
\end{abstract}

Keywords: culture; humanness; knowledge sharing; Malaysia 


\section{Introduction}

Sharing knowledge with colleagues or managers is important within organizations due to the innovative potential to generate new ideas and develop new business opportunities through socialization and learning processes of knowledgeable workers (Darroch and McNauthon 2002). Additionally, the knowledge sharing literature states that the performance of an organization can only be increased when an organization is learning from the market (Slater and Narver 1995). To accomplish a knowledge sharing environment, organizations must face some tough challenges. According to Lin et al. (2009) some of these knowledge sharing challenges are:1) the need to create mutual trust between actors;2) the ability and willingness to make explicit and formulized, highly personal knowledge;3) to overcome resistance and realize that knowledge sharing behavior is voluntary and, finally;4) to share knowledge means sharing of power, which can be seen as giving up a competitive advantage compared to colleagues.

Knowledge encompasses the utilization of information and data which is combined with people's skills, competencies, their ideas, intuitions, commitments, and motivations to use information in a way that meets the objective of individuals or an organization (Tan 2000). The learning process of knowledge sharing needs to be encouraged and improved by managers within the organization to develop a continuous experimental environment. This means that the involvement of managers is key in the knowledge sharing process of organizations. Moreover, a certain style of leadership is needed to create a situation where employees feel free to experiment and exchange knowledge instead of being held responsible for possible failures.

As is mentioned previously, knowledge sharing is a human skill which stimulates business. Unfortunately, it is difficult to motivate employees to share their knowledge when the advantages are not a personal favor. Several scholars (Lin and Lee 2004; Lu et al. 2003; MacNeil 2004; Taylor and Wright 2004) found evidence that managers can act as leaders and mentors which will help stimulate employees to begin sharing knowledge. Knowledge sharing will be influenced by the way in which managers manage. Thus, the reason why we pay attention to the management style they follow.

In the literature, an interesting phenomenon is discovered which is called humanness. This, from its origin in African management style, is based on the four fundamental dimensions, namely Solidarity, Survival, Compassion and Respect and Dignity. A recent study (Scholtens 2011) found a strong relationship between humanness and the willingness to share knowledge between managers and employees in Tanzania. The strong focus of the managers on these important cultural factors stimulated employees to share information with others. How will this be in the Malaysian context? Additionally, how will this be influenced by the enormous cultural diversity within the Malaysian context?

Within this research, the main focus will be on the relationship between knowledge sharing and humanness in Malaysia, and it will be compared to the results of Tanzania. Furthermore, the differences between the cultures of the three ethnicities and their influence on knowledge sharing is researched. 


\section{Conceptual Model}

\section{Knowledge Sharing}

With the fast moving global environments, the storage of information or knowledge about opportunities and threats within markets becomes more important. The quality of knowledge and the knowledge processes in organizations are seen as the key business activities that make an organization successful in competitive marketplaces (Housel and Bell 2001). Additionally, Slater and Narver (1995) state that the performance of companies can only be improved by learning from the market. According to these authors, a 'market-driven' organization is able to anticipate the changing needs of consumers by using knowledge to develop innovative products and services. Using this knowledge will create advantages for these market driven organizations as it enables them to respond quickly and effectively to opportunities and threats, which makes market orientation actually a learning orientation process. To gain from these knowledge learning processes, knowledge sharing within the organizations is important. Darroch and McNaughton (2002) define knowledge sharing as 'a form of organizational innovation that has the potential to generate new ideas and develop new business opportunities through socialization and learning processes of knowledge workers.' Furthermore, Lin, Lee and Wang (2009) define knowledge sharing as 'a social interaction culture involving the exchange of employee knowledge, experiences and skills through the whole department or organization.' This implies that knowledge sharing is influenced by cultural aspects and that cultural norms and values have an impact on the willingness of employees to share knowledge within an organization. In their research about knowledge sharing, Lin et al. (2009) identified four dimensions which capture the most influential factors of knowedge sharing which are; Corporate Culture, Management and Leadership, Employee Motivation and Information Technology. The dimensions of knowledge sharing are explained in Appendix 4.

\section{Humanness}

According to Mbigi $(1997,2000)$ who sees himself as the founder of the humanness philosophy, Africa should stop imitating the Western business styles and use its own heritage which is based in their culture. Moreover, 'the African life emphasized humanity and relationships over material wealth' (Shonhiwa 2006). The cornerstones of humanness define the management concept and are used and developed by several scholars (Broodryk 2005; Pooven et al. 2006; Sigger et al. 2010). These dimensions are Solidarity, Survival, Compassion and Respect and Dignity and are referring to the relationships between people within communities. The dimensions of humanness are explained in Appendix 5. Humanness(as labeled by Sigger et al. 2010) is a philosophy that brings people together regardless of their background or their access to wealth and can be seen as a unifying factor (Sithole 2001).

Scholtens (2011) has started to conduct empirical research in Tanzania on the relationship between humanness and the willingness to share knowledge between Tanzanian managers within organizations and discovered a strong correlation between the two concepts. 


\section{The Relation between Knowledge Sharing and Humanness}

This research is based on the findings by Scholtens (2011) in Tanzania, who found a strong relationship between the concepts of humanness and knowledge sharing. This means that, with the use of important cultural cornerstones, it is possible for managers to encourage their employees to share knowledge.

The direct relationship between knowledge sharing is interesting, but a closer look at this relationship is also interesting when we realize that both concepts, humanness and knowledge sharing, can be described with the assistance of dimensions. These independent dimensions are influencing each other, though it is not clear to what degree.
For example, how much influence does Solidarity have on Employee Motivation? Figure 1 illustrates the relationships this research will examine to determine whether there is a difference in influence of the independent dimensions.

Although a strong relationship was found between humanness and knowledge sharing, some negative relationships were also found by Scholtens. His findings indicated a negative relationship between solidarity and the willingness to share knowledge. Furthermore, a low presence of humanness was found in the dimensions Information Technology. Based on the findings of Scholtens, a comparison with the current study will be made. The data found by Scholtens will be useful to determine the degree of influence humanness has on knowledge sharing.

Figure 1. The Relation between the Dimensions of Knowledge Sharing and Humanness

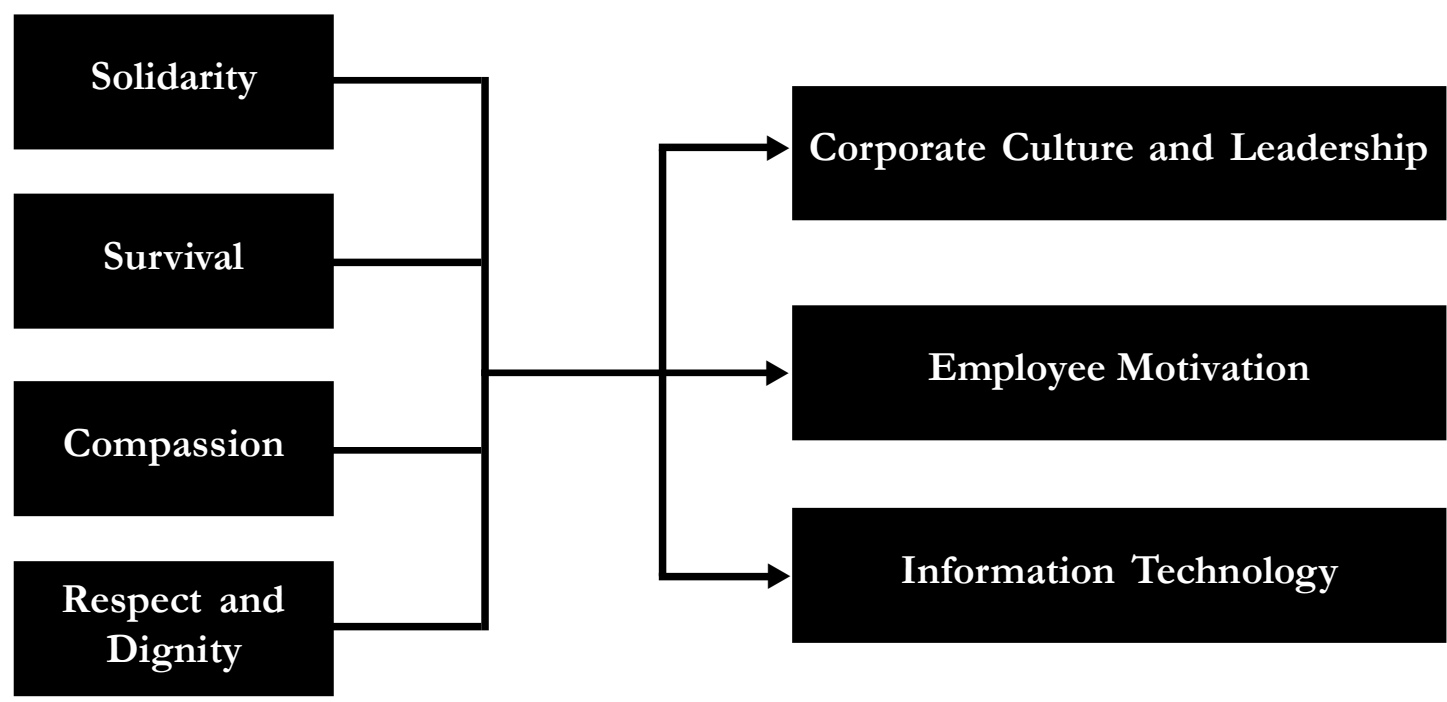




\section{Setting the Research Scene (Malaysia)}

The relatively advanced developing countries, whose scope and scale of industrial production is growing rapidly and who have a highly competitive export sector, can be called Newly Industrialized Economies (NIE) (Sibert 2007). One of these NIE countries is Malaysia.The country is developing rapidly after leaving the colonial heritage behind. Major changes have been carried out which are shown in the strong growth rates of 5-6 percent and the increase in GNP in 2010. Although these numbers are fascinating, the Malaysian Government wants more and has developed a plan to change the country from a production-based economy into a knowledge-based economy. These plans were already made in 2002 and redefined in 2005, however, only minor changes have been implemented, and Malaysia is still not seen as a knowledge hub (Syed-Ikhsan and Rowland 2004).

Furthermore, Syed-Ikhsan et al. (2004) state that the role of managers is an important factor to stimulate knowledge sharing within an organization. They need to create an environment where employees are ensured of sharing knowledge without the the nuisance of cultural barriers. Furthermore, the results of Cheng et al. (2009) showed that the Malaysians are aware of the changes the government wants to implement to become a knowledge-based economy. However, their participation in this process is low, which implies that managers could have an important influence on this process. In a globalized world, it is good to learn more from other places in the world, and a focus on how people can work together and the way this is managed can be compared to the studies done on management styles in Africa.

\section{Malaysia?}

Within the Malaysian values, family is the most important aspect and members of a family help each other no matter what the issue is. This is in line with the studies of the Global Leadership and Organizational Behavior Effectiveness (GLOBE) which compare cultures and attributes of effective leadership in 61 countries, including $\mathrm{Ma}$ laysia (House et al. 2002; 2010). According to these studies, Malaysia scores high on the GLOBE cultural dimension of human orientation, which entails that they have the tendency to see others, such as family, friends or the community,as more important. Human oriented societies are motivated by the need for belonging and affiliation where the values such as love, kindness, altruism and generosity are essential. Looking at the main cultural norms and values of Malaysian employees, they are similar to the dimensions of humanness which are based on the strong communal relationship and the need to help each other.

Although the Malaysian Government is campaigning with the slogan '1 Malaysia' which means that,despite the cultural differences between the inhabitants,everyone lives in harmony with each other; however, the opposite is true. This is the conclusion of the study conducted at Nestlé Malaysia by Zawawi (2008). In this research, several employees from different backgrounds discussed their daily business and explained the difficulties they face in these practices. The respondents argued that miscommunications and misunderstandings were caused by the lack of cultural knowledge of other ethnic colleagues.

To understand these differences, more is explained about the important norms and 
values of the main ethnicities present in Malaysia. For instance, the Malays are, by the Malaysian Constitution, Muslims which means that they strongly believe in the concept of Allah the Almighty. In the Koran, it is said that there is an equal benefit of resources for everyone that should be acquired rightfully and is in line with guidelines that businessman take social goods into their consideration in business for reasons other than making a profit (Rice 1999). Therefore, Malays expect their managers/leaders to act as role models who value the religion and spirituality of the group (Zabid and Ho 2003).

Within the Chinese community, values such as ambition and being successful are more common. Factors such as education, wealth or prosperity, respect of face, improving oneself and harmony are important (Zabid and Ho 2003). Furthermore, the Chinese are regarded as workers who are target oriented and motivated by financial rewards (Sendut 1991). The third large ethnicity present in Malaysia are the Indians who are living more according to rituals and traditions such as the caste system and the belief in rebirth (Nordin and Hussin 2004). With these beliefs, the Indians strive hard to gain authority, self-confidence and self-respect (Zawawi 2008). Within organizations, Indians are seen as loyal people who work hard. They have a high tolerance and are keen on adapting to the rules and structures of a company.

\section{Research Methods}

\section{Sample}

Questionnaires were distributed among managers from Malaysian organizations. From every industry, managers were asked to participate in the research.Managers from the public sector, however, were lesswilling to respond to any e-mails or phone calls. The total response of the questionnaires is 214 which is, according to the statements of Thomas (2004), enough when the sample size is unknown. Of the participants, 125 $(58 \%)$ are men and $89(41.6 \%)$ women. Furthermore, the participants were asked to fill in their ethnicity which provided surprising results. The majority (47\%) are Chinese, the Malay account for 22 percent and the Indians 9.3 percent. Another large group were the managers who are not originally from Malay$\operatorname{sia}(17.8 \%)$.

\section{Scales and Measures}

The presence of humanness and the willingness to share knowledge in organizations was measured using a survey of 47 questions (shown in Appendix 1). Respondents were asked to which degree they agreed with the statements, using a five-point Likert scale (ranging from $1=$ strongly disagree to $5=$ strongly agree). To avoid similarities in answers, the items were grouped randomly representing the four dimensions of humanness and the three dimensions of knowledge sharing. As is mentioned before, this study compares the results of humanness and the relationship to knowledge sharing of Tanzania to Malaysia. In the study by Scholtens (2011), some adjustments were made because the dimensions of Corporate Culture and Leadership and Management included many similarities and, therefore, these dimensions are seen as one.They are used in this study as well. Three dimensions for knowledge sharing remain.

\section{Variability and Reliability}

The scales used in the questionnaire are tested by using Cronbach's alpha to determine 
whether there is an internal consistency or average correlation of items. The perfect output of the Cronbach's alpha coefficient has a scale above 0.7. In AppendixII, the tables of the Cronbach's alpha coefficients of knowledge sharing and humanness of both countries are shown. Both countries show a higher score than 0.7 which indicates that the questions measure the same underlying construct.

\section{Analysis and Results}

First the presence of humanness in Malaysia is investigated. This is done by using the same measurement tool Scholtens (2011) used, which is developed by Sigger et al. (2010) to calculate the presence of humanness in a country. In this measurement tool, the means of the individual dimensions are used to measure the level of humanness.
Scores of 2.4 or less indicate a low level of humanness. Scores between 2.5 and 3.5 indicate a moderate level of humanness, and scores of 3.6 or higher indicate a positive high level. In this study, it is expected that, in the comparison to Tanzania, Malaysia will score lower on the humanness dimensions Solidarity, Survival and Compassion because these values are basics in the African culture. However, it is expected that Malaysia will score higher on the dimension Respect and Dignity due to the high exposure of cultural differences as is explained by the respondents in the study of Zawawi (2008).

Figure 2 visualizes the results of the Malaysian respondents compared to the managers of Tanzania. First, the results show that the Malaysian managers score more than 3.6 on all dimensions of humanness. In comparison, the results for the Tanzanian managers

Figure 2. Humanness Dimensions Compared for Malaysia and Tanzania

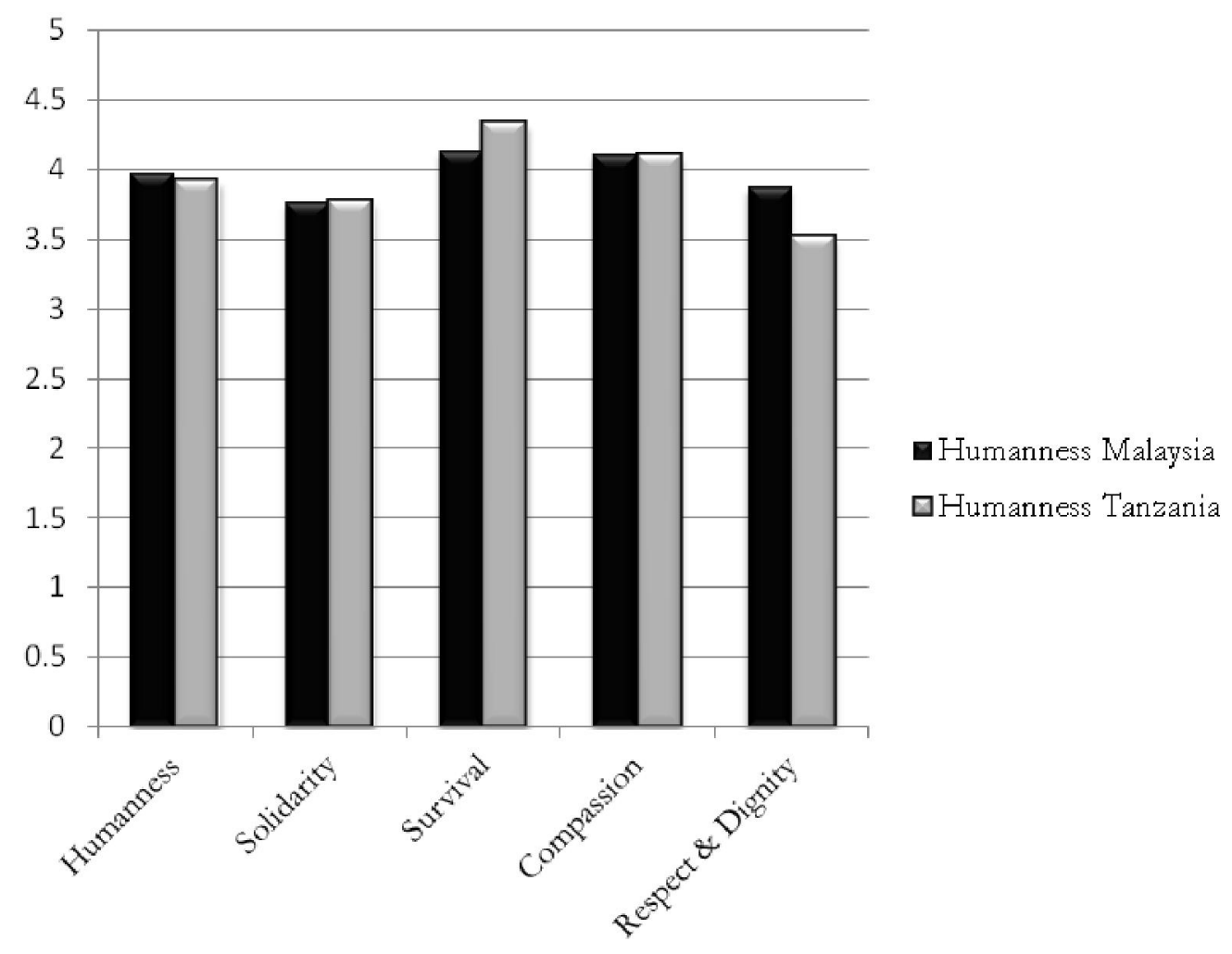


are, in general, the same. Although it was expected to find larger differences, one assumption proved to be true. The Malaysian managers scored higher on the dimensions Respect and Dignity compared to Tanzanian managers, emphasizing the results of Zawawi (2008).

In line with the aforementioned findings, it is possible to research whether there is a relationship between the willingness to share knowledge and humanness in Malaysia. To calculate this relationship, it is necessary to see if these variables correlate with each other. Using the Pearson correlation coefficient, a possible linear relationship between the dimensions of knowledge sharing and humanness in Malaysia is calculated. In Appendix III, it is shown that there exists a moderate/strong linear relationship between most variables with the exception of the dimension Information Technology. It is weaker than the others, suggesting that the relationship is minimal. The results makes it possible to use the one-on-one Regression Analysis and the Multiple Linear Regression Analysis to analyze to what extent the vari- ables knowledge sharing and humanness are related. First, the relationship between the variables knowledge sharing and humanness is studied. Looking at the coefficient of determination, the R-Square shows a value of 0.618, which is quite high for this kind of research. The degrees of freedom are $\mathrm{F}=$ 560.900 with a significance of $p<0.000$. From these results, it can be said that 61.8 percent of the variability of knowledge sharing is explained by the presence of humanness (see Figure 3). The coefficient of humanness shows a $\beta 0.786$ which means that humanness has a linear positive effect on knowledge sharing in Malaysia.

In comparison to Tanzania, the scores of the latter are slightly lower with a variability percentage of 49.3 percent (Scholtens 2011). Additionally, the $\beta$ of Malaysia is 0.786 and for Tanzania the $\beta$ is 0.780 . This means that the differences between the countries in the relationship between knowledge sharing and humanness is not large. The difference in explained variances between both countries might be a new research question for follow-up research.

Figure 3. Malaysia and Tanzania Compared in the Relationship between KS and $\mathbf{H}$

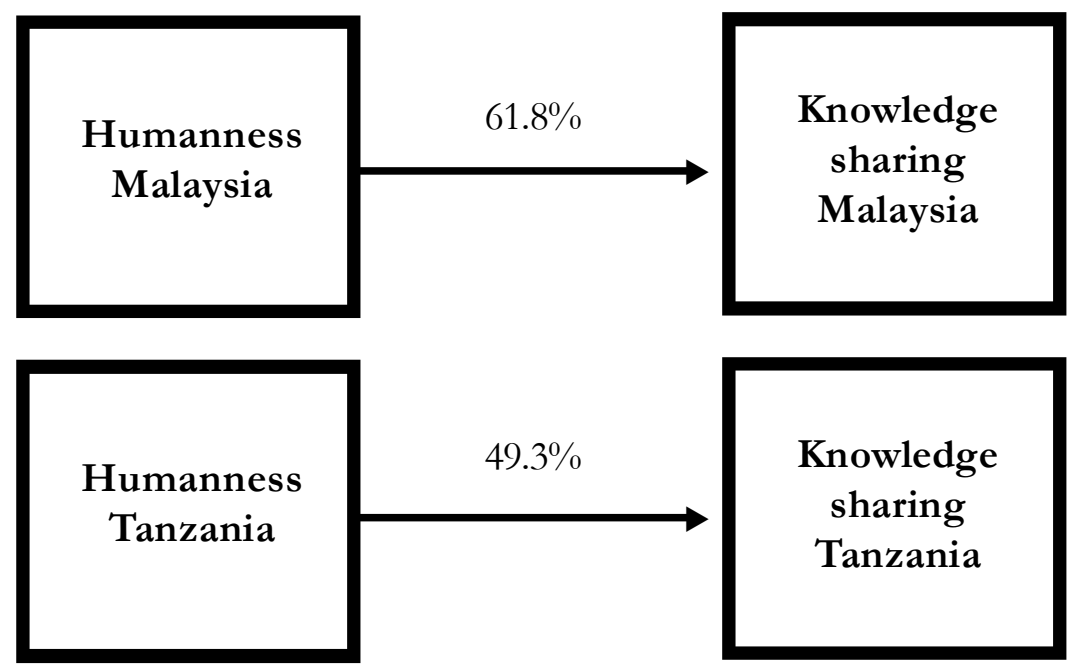




\section{Figure 4. The Influence of the Humanness Dimensions on Knowledge Sharing}

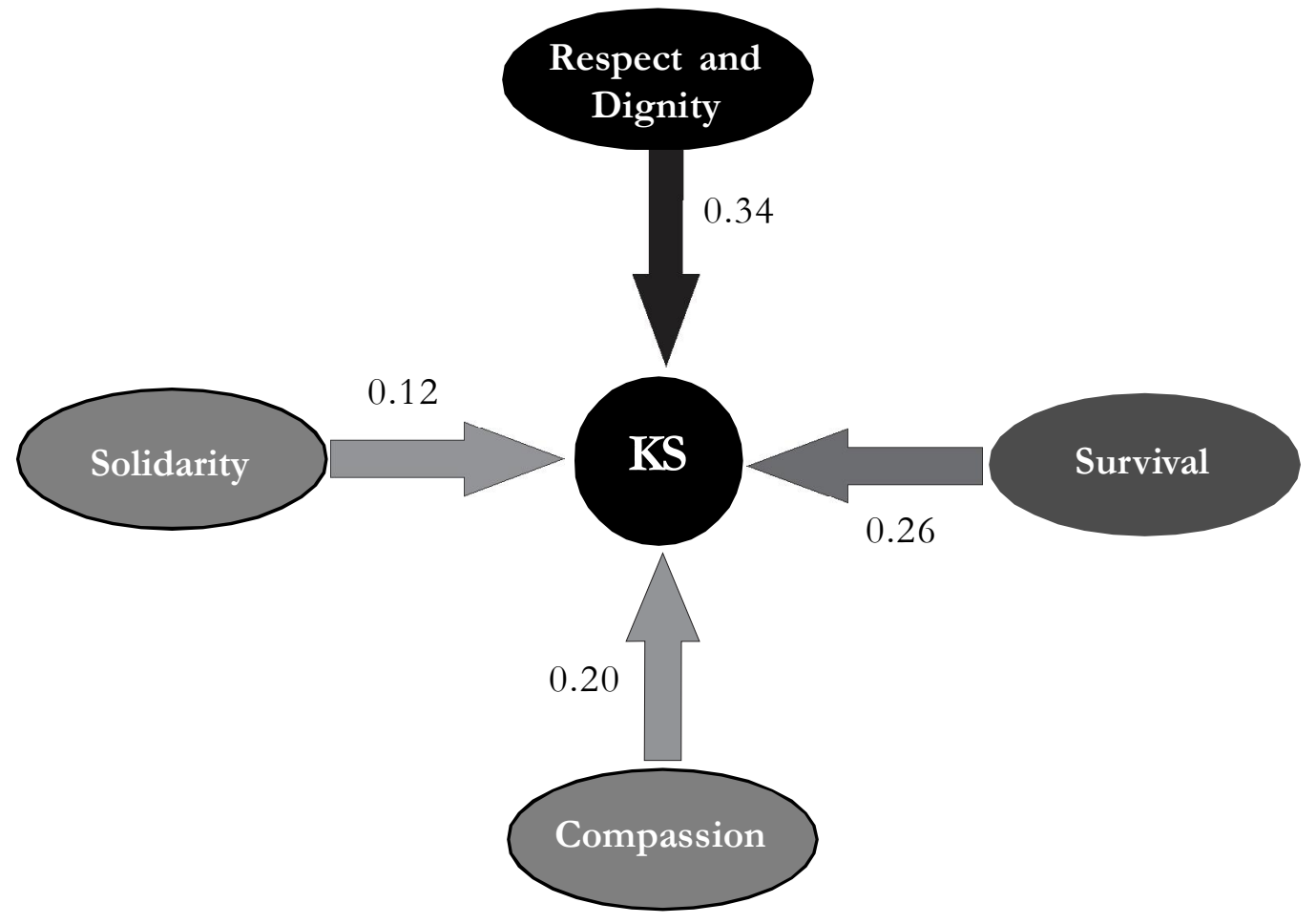

Now that the relationship between knowledge sharing and humanness is found, it is interesting to more closely inspect the dimensions of both concepts and analyze to what degree the individual dimensions influence each other. First, the influence of the individual humanness dimensions on knowledge sharing is investigated and is shown in Figure 4. The results from the Regression Analysis illustrate that all individual humanness dimensions have a positive influence on knowledge sharing (Solidarity 0.12; Survival 0.26; Compassion 0.20; Respect and Dignity 0.34). From this information, it can be concluded that the humanness dimensions have influence on knowledge sharing, which means that cultural values are important factors in the willingness of managers to share knowledge.
In addition to the influence of the individual dimensions on knowledge sharing, this study looks at the influence of the humanness dimensions on the individual knowledge sharing dimensions of Corporate Culture and Leadership (CCL), Employee Motivation (EM) and Information Technology (IT).

For Corporate Culture and Leadership, the Multiple Regression Analysis (Figure 5) shows an R-Square of 0.74 , explaining 74.4 percent of the variability is explained by the individual humanness dimensions. However, it is notable that there is a negative relationship between Solidarity and Corporate Culture and Leadership. Additionally, not all dimensions have a significance of $\mathrm{p}<0.01$. 
Figure 5. The Influence of Humanness Dimensions on Corporate Culture and Leadership

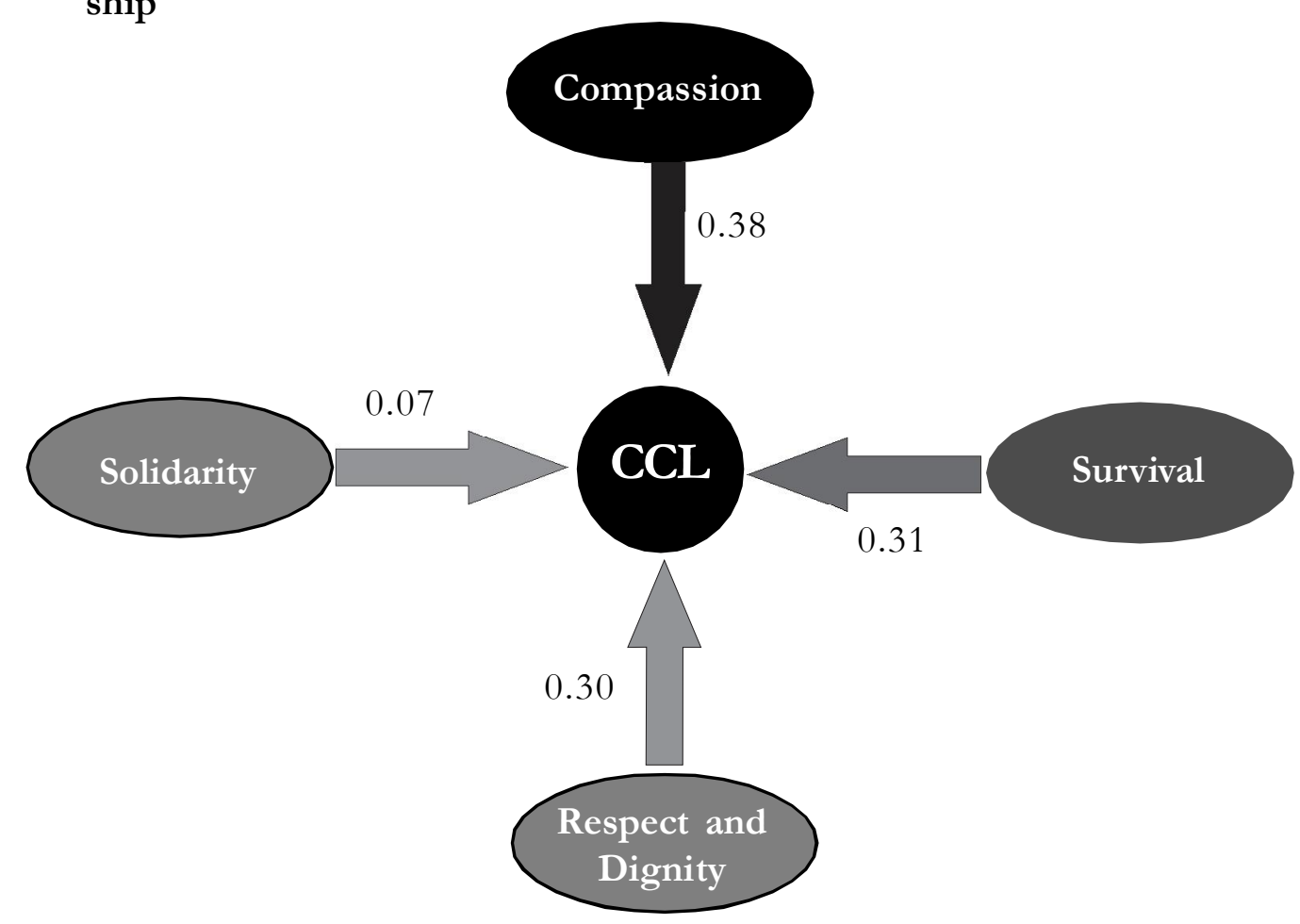

Figure 6. The Influence of Humanness' Dimensions on Employee Motivation

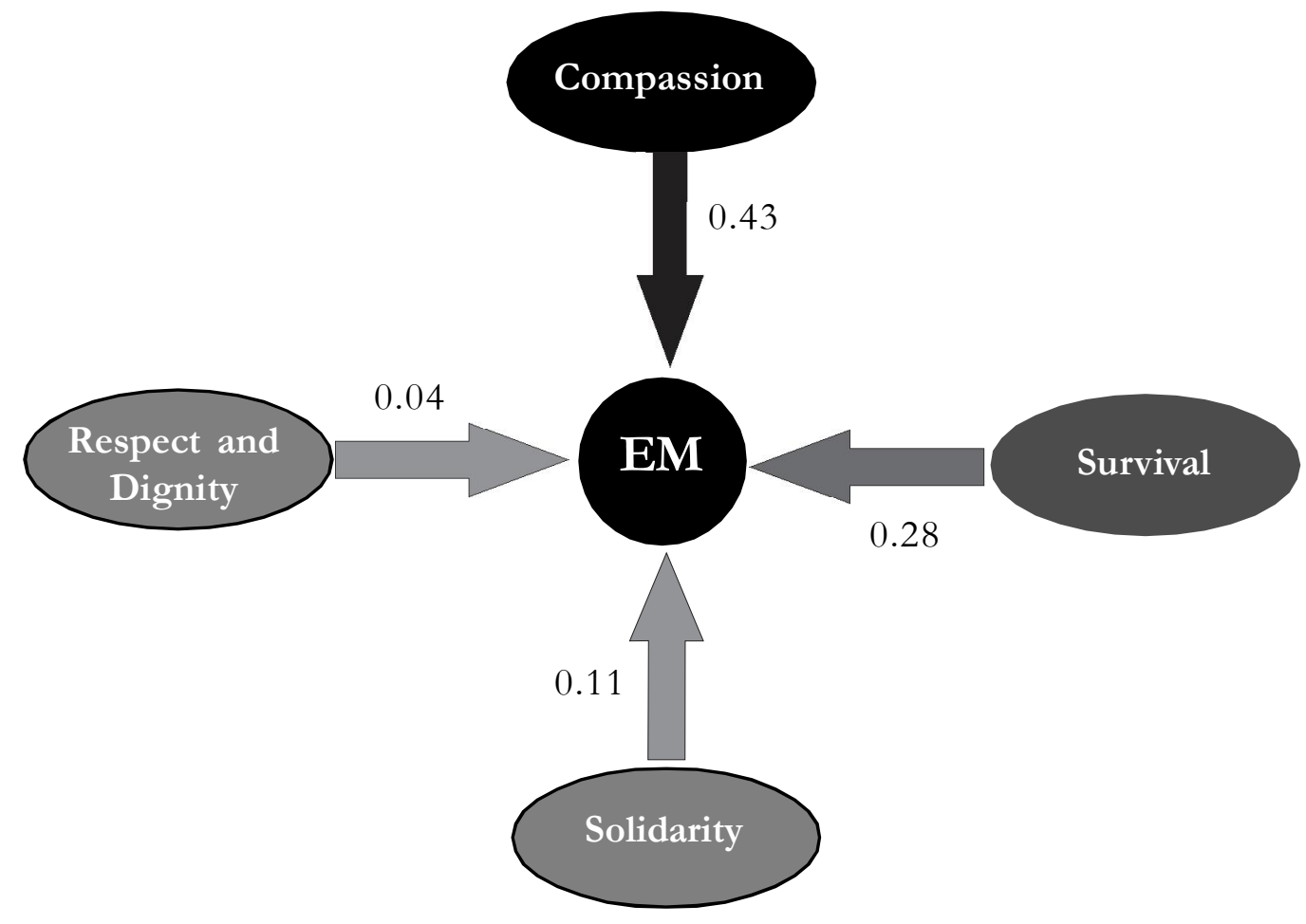


The dimension Employee Motivation, Figure 6, has a lower R-square than the previous dimensions. The $\mathrm{R}$-square is namely 0.65 , which means that 65 percent of the variance in Employee Motivation is caused by the humanness dimensions. In contrast to the former dimension, all humanness dimensions have a positive relationship, though they are not very high; Compassion 0.43; Survival 0.28; Solidarity 0.11; Respect and Dignity 0.04 .

Finally, the variance of Information Technology is calculated. The R-Square is 0.34 which means that 34 percent of the variability is explained by the humanness dimensions and is the lowest score of all knowledge sharing dimensions which is illustrated by Figure 7. Furthermore, a negative relationship is found between Information Technology and Respect and Dignity indicating that modern technology does not have an influence on human values. As shown in Figure 7, the scores of the humanness dimensions on Information Technology are not high, which is similar to the low findings of the Pearson correlation coefficient.

The diversity of cultures in Malaysia is unique and makes it an interesting topic for research. In this study, the respondents were asked to fill in their ethnicity which led to the aforementioned distribution of the participants. The high participation of Chinese managers is in contrast to the majority of Malays in Malaysia (60\% versus 30\%). However, according to Arlès (1971), the differences between this research and the statistics of Malaysia is due to the dominance of Malays in the public sector which is offset by the economic prominence of the Chinese. For this research, the Malaysian governmental institutes were not able to participate and, therefore, this is a valid explanation for the differences in distribution.

\section{Figure 7. The Influence of Humanness Dimensions on Information Technology}

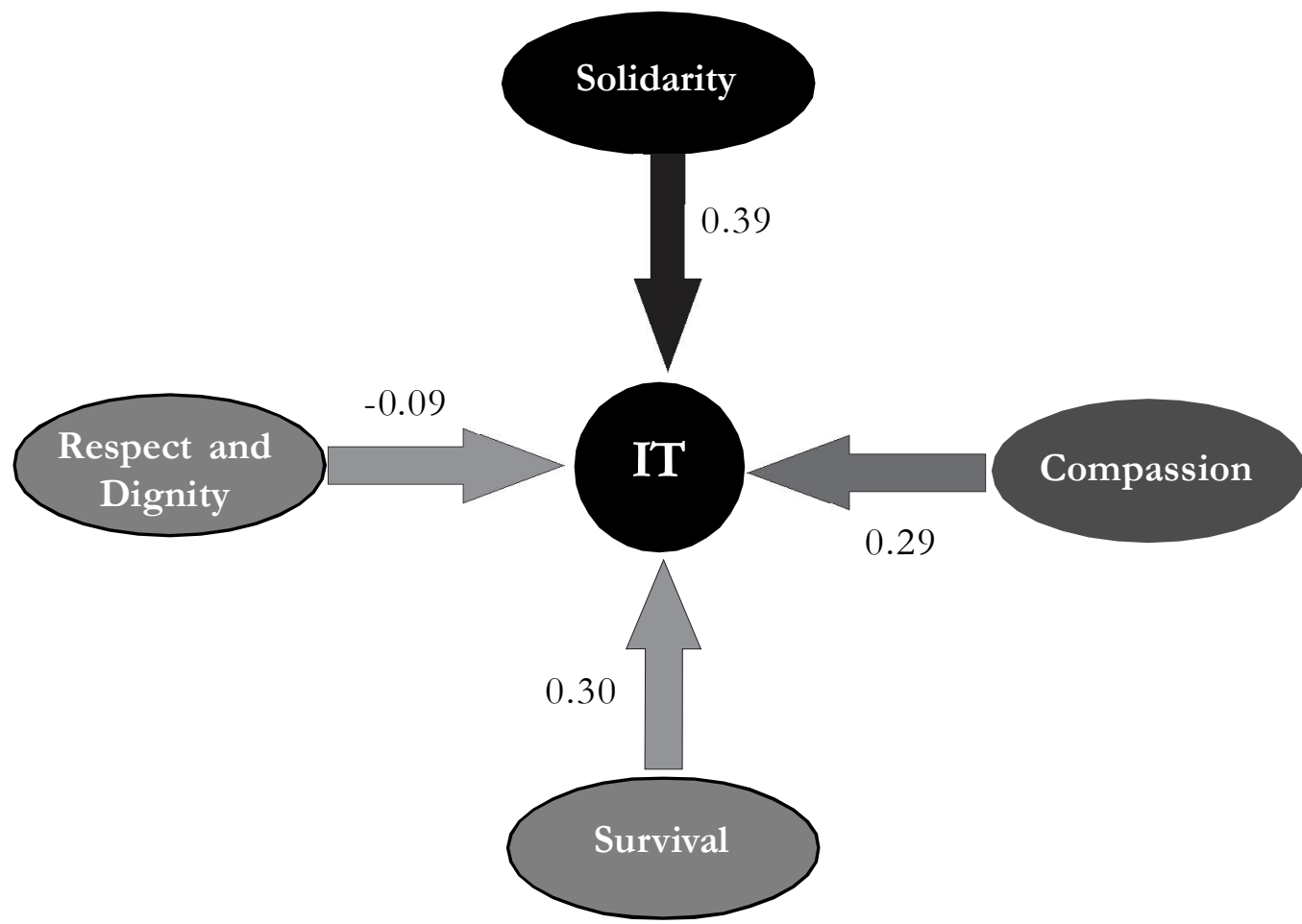


Figure 8. The Humanness Dimensions Compared between Ethnicities Using ANOVA

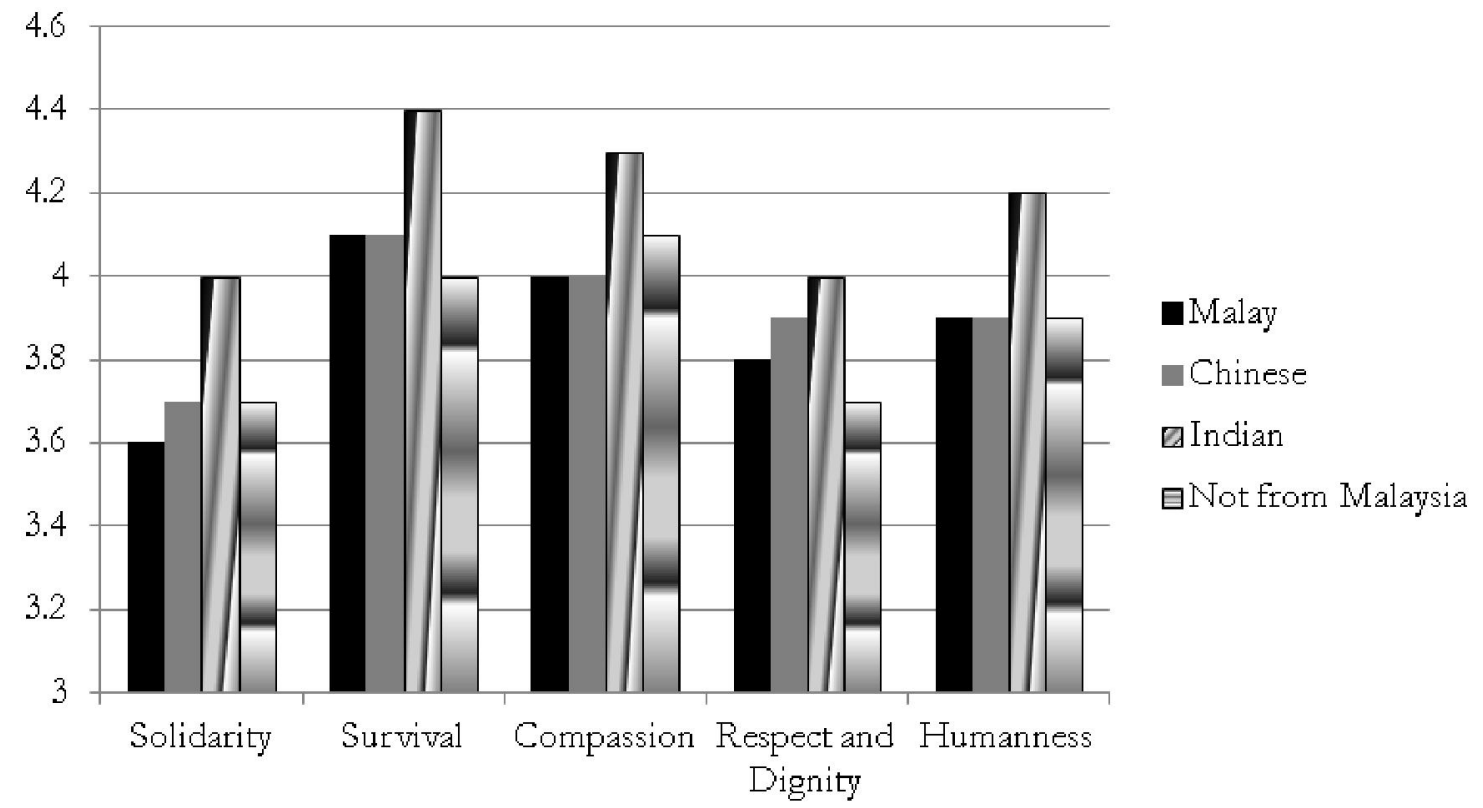

As mentioned before, the differences between the ethnicities are found in their norms and values. Malays live according to the rules of Islam, Chinese are hard workers and entrepreneurial and the Indians live their lives to acquire a higher caste in rebirth. During the data collection process, it became apparent that a fourth group should be included in the research indicated as the managers not from Malaysia. This group includes the international managers from around the world living and working in Malaysia and could not be ignored due to its large presence $(17.8 \%)$.

The four ethnicities were first examined for their presence of the humanness dimensions Solidarity, Survival, Compassion and Respect and Dignity using the one-way ANOVA. Although the literature suggests there are differences in viewpoints with respect to cultural norms and values, the Homogeneity of Variances shows $\mathrm{p}>0.05$ indicating equality between the groups. Further- more, the Levene's test shows that the differences in variance are not attributed by chance and, therefore, the results can be used. Figure 8 shows that all the ethnicities have a score of 3.6 or higher, explaining the presence of the humanness dimensions in all ethnicities and showing small differences between the groups.

Calculating the sum of squares between the groups and dividing this by the total sum of squares reveals the exact differences for the humanness dimensions which are 2.7 percent for Solidarity, 3.6 percent for Survival, 1.8 percent for Compassion and 2.6 percent for Respect and Dignity. Even the use of dummy variables could not find any of the expected differences between the ethnicities. Furthermore, it was expected that the Malays and their Islamic norms and values were more in line with the humanness dimensions compared to the other ethnicities. In Figure 7, the opposite is true which means that the assumption is rejected and that the other ethnicities 


\section{Figure 9. The Knowledge Sharing Dimensions Compared between Ethnicities Using ANO}

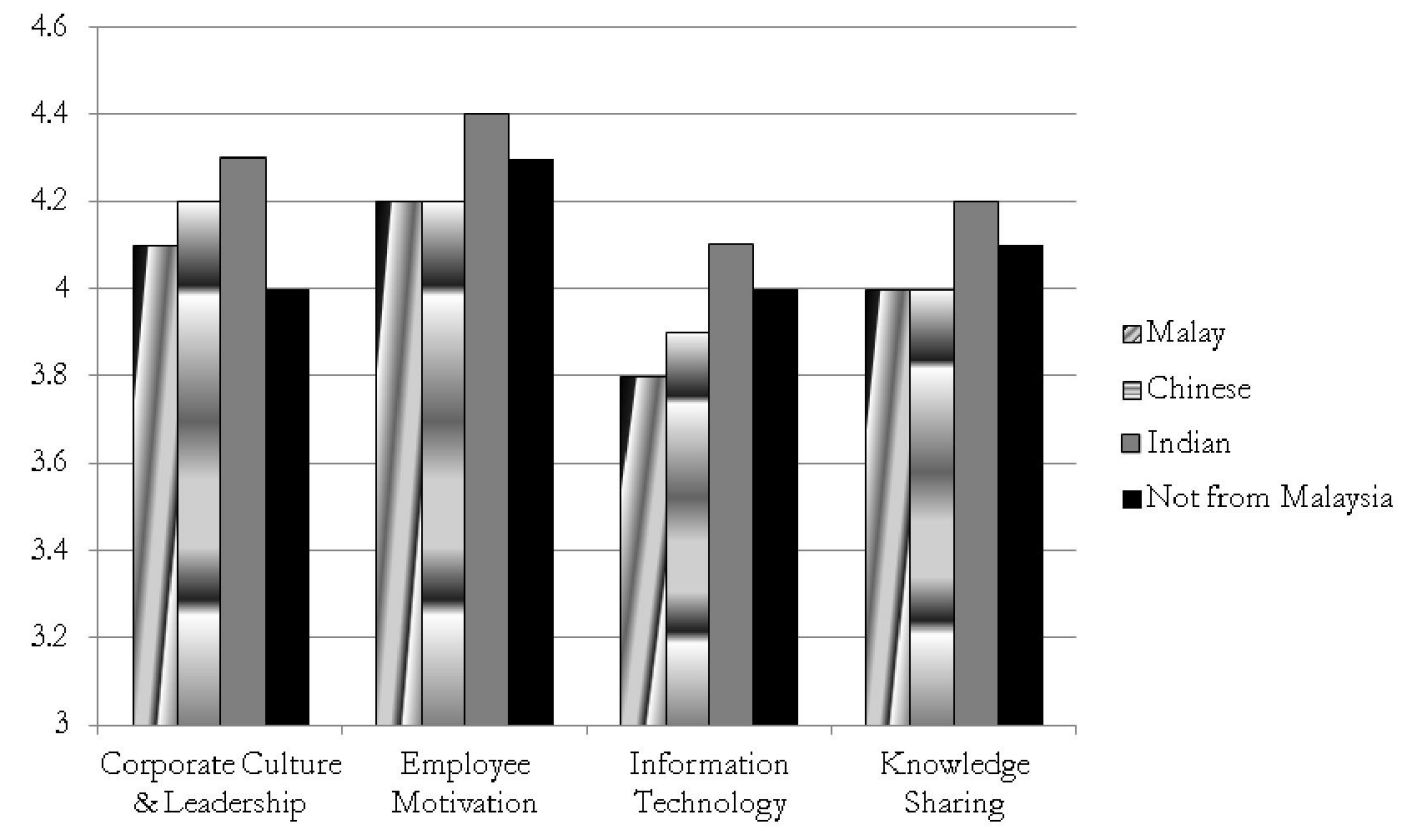

score equally high or even higher than the Malays. Surprising is the high score of the Indians on all dimensions, which is in contrast to the findings from the literature. From the data results, the Indians score highest on all humanness dimensions, suggesting that this ethnicity is most in line with the dimensions of humanness.

Along with investigating the presence of humanness, the presence of knowledge sharing is investigated, revealing similar results to the humanness dimensions, as is shown in Figure 9. The Homogeneity of Variance shows $\mathrm{p}>0.05$ and, according to the Levene's test, the results are not found by chance. The findings are all above the scale of 3.6 and quite similar to each other, meaning that all managers of the ethnicities are willing to share knowledge with each other.

Even the dummy variable found an Rsquare of 0.017 showing 1.7 percent of the differences between the ethnicities is ex- plained by knowledge sharing. Furthermore, the Indians have a higher score on these dimensions as well. Although the differences are smaller compared to the humanness dimensions, the results suggest that Indians are more willing to share knowledge compared to the Malay, Chinese and managers not from Malaysia. Surprising is the conclusion that the ethnicities have a similar score for both humanness and knowledge sharing, indicating that mutually cultural aspects such as the willingness to share knowledge are highly present in Malaysia.

\section{Conclusion}

The main objective of this study was to find a relationship between the humanness management style and the willingness to share knowledge of managers from Malaysia and the possibility of difference when the ethnic background of managers was taken into ac- 
count. Due to the findings of Scholtens (2011) in Tanzania, a strong positive relationship is expected between these two concepts. For a developing country such as Malaysia, knowledge is essential for the transformation from a production-based economy to a knowledge-based economy. With the results of this research, it can be stated that human management or people management has a strong influence on the willingness to share knowledge within organizations. Therefore, it is important for companies to know that human aspects such as culture and norms and values influence a learning environment, which means that managers can encourage their employees to share knowledge with eachother.

Furthermore, the regression analysis shows the relationships between the humanness and knowledge sharing dimensions. However, not all relationships proved to be positive or high, and especially the relationships concerning Information Technology proved to be low. The relation with Respect and Dignity was even negative. From these relationships, it can be concluded that IT and human norms and values are correlating less compared to the other relationships which is surprising because digital communication is becomingmore popular every day. Therefore, it would be interesting to investigate this relationship in future research.

Although the literature suggests otherwise, minor differences were found between the four different ethnicities living in Malaysia. The results show that the cultural heritage of Malaysian managers is not visible in the behavior of managers towards their employees and, therefore, it can be concluded that different cultural backgrounds of managers does not influence the willingness to share knowledge in Malaysian organizations. The findings of this research do suggest that managers should apply more human oriented management skills such as Solidarity, Survival, Compassion and Respect and Dignity to encourage their employees to share more knowledge between each other. This leads to an environment where knowledge transfer between co-workers is encouraged and employees no longer fear making errors or saying something wrong.

\section{Options for Future Research}

The results of this research show there is a strong positive relationship between humanness and knowledge sharing in Malaysia. This is important information for the Malaysian Government in their development plan. All of our respondents are working in the private sector, and a variety of them have their own business, while many potential respondents work in the public sector which is also important for this research on management styles. However, it is difficult to contact governmental offices or institutions. Nevertheless, it is interesting to investigate whether humanness and the willingness to share knowledge are strongly related in this sector since many Malay inhabitants work at governmental institutions. Moreover, it is interesting whether the Malay cultural norms and values are highly present in this sector and if this has any influence on the knowledge transfer within the government. Although this research found no difference in the cultural norms and values used by managers from various ethnic backgrounds, this could be different in the public sector due to the high presence of Malay employees. Furthermore, the work ethics and bureaucratic system of the public system is different from private businesses and, therefore, it would be interesting to see whether the two sectors are similar or different. 


\section{References}

Arlès, J. P. 1971. Ethnic and socio-economic patterns in Malaysia. International Labor Review 104: 534.

Broodryk, J. 2005. Ubuntu Management Pbilosophy. Randburg, South Africa: Knowres.

Cheng, M. Y., S. Hossain, and J. H. Guo. 2009. Social acceptance and readiness for the knowledge-based economy in Malaysia. ASEAN Economic Bulletin 26 (3): 253-65.

Darroch, J., and R. McNaughton. 2002. Examining the link between knowledge management practices and type of innovation. Journal of Intellectual Capital 3 (3): 210-222.

House, R. J., N. R. Quigley, and de M. Luque. 2010. Insights from Project GLOBE, Extending global advertising research through a contemporary framework. International Journal of Advertising 29 (1): 111-139.

House, R., M. Javidan, P. Hanges, and P. Dorfman. 2002. Understanding cultures and implicit leadership theories across the globe: An introduction to project GLOBE. Journal of World Business 37: 3-10.

Housel, T., and A. H. Bell. 2001. Measuring and Managing Knowledge. New York: The McGraw-Hill Companies, Inc.

Lin H. F., and G. G. Lee. 2004. Perceptions of senior managers toward knowledge-sharing behaviour. Management Decision 42 (1): 108-125.

Lin,H. F., H. S. Lee, and D. W. Wang. 2009. Evaluation of factors influencing knowledge sharing based on a fuzzy AHP approach. Journal of Information Science 35 (1): 25-44.

Lu, L., K. Leung, and P. T. Koch. 2006. Managerial knowledge sharing: the role of individual, interpersonal, and organizational factors. Management and Organization Review 2 (1): 15-41.

MacNeil, C. M., 2004. Exploring the supervisor role as a facilitator of knowledge sharing in teams. Journal of European Industrial Training 28 (1): 93-102.

MacNeil, C. M. 2003. Line managers: Facilitators of knowledge sharing in teams. Employee Relations 25 (3): 294-307.

Mbigi, L. and J. Maree. 2005b. Ubuntu: The Spirit of African Transformation Management. Randburg, South Africa: Knowres.

Nordin, M., and H. Hussin. 2004. Pengajian Malaysia. Kuala Lumpur: FajarBakti Sdn. Bhd.

Poovan, N., M. K. A. Du Toit, and A. S. Engelbrecht. 2006. The effect of the social values of Ubuntu on team effectiveness. South African Journal of Business Management.

Rice, G. 1999. Islamic ethics and the implications for business. Journal of Business Ethics 18 (4): 345-358.

Scholtens, C. 2011. The Innovative Value of Ubuntu: Knowledge sharing in African Organizations.

Sendut, H. 1991. Managing in a multicultural society? the Malaysian experience. Malaysian Management Review 26 (1): 61-69.

Shonhiwa, S. 2006. The Effective Cross-Cultural Manager: A Guide for Business Leaders in Africa. Cape Town: Zebra Press.

Siebert, H. 2007. The World Economy: A Global Analysis (3 ${ }^{\text {rd }}$ ed.). London: Routledge.

Sigger, D. S., B. M. Polak, and B. J. W. Pennink. 2010. 'Ubuntu' or 'humannes' as a management concept. CDS Research Paper 29. 
Sithole, J. 2001. Africa Can Only Use Own Culture to Influence Globalization. Afrol [African Online Services] News, http://www.globalpolicy.org/globaliz/cultural/ 2001/0515afr.htm. Accessed 14 May 2009.

Slater, S., and J. C. Narver. 1995. Market orientation and the learning organization. Journal of Marketing 59: 63-74.

Syed-Ikhsan, S.O.S., and F. Rowland. 2004. Knowledge management in a public organization: A study on the relationship between organizational elements and the performance of knowledge transfer. Journal of Knowlegde Management 8 (2): 95-111.

Tan, J. T. L. 2000. Knowledge management- Just more buzzwords? The British Journal of Administrative Management (Issue 19): 10-11.

Taylor, W.A., and G. H. Wright. 2004. Organizational readiness for successful knowledge sharing: Challenges for public sector managers. Information Resources Management Journal 17 (2): 22-37.

Thomas, A. 2004. Research Skills For Management Studies. Routledge

Zabid, A. R. M., and J. A. Ho. 2003. Perceptions of business ethics in a multicultural community: The case of Malaysia md. Journal of Business Ethics 43 (1/2): 75-87.

Zawawi, D. 2008. Cultural dimensions among Malaysian employees. International Journal of Economics and Management 2 (2): 409-426. 


\section{APPENDIX I. QUESTIONNAIRE RESPONDENTS}

What is your gender?

What is your ethnicity?

o Woman
o Man

o Malay

o Chinese

o Indian

o Mixture

o I am not from Malaysia

For the following questions, please indicate in how far you agree with the statement, ranging from 'I strongly disagree' to 'I strongly agree.'

\begin{tabular}{|c|c|c|c|}
\hline \multirow[b]{2}{*}{ The organization encourages teamwork } & $\begin{array}{l}\text { Strongly } \\
\text { Disagree }\end{array}$ & $\begin{array}{r}\text { Strongly } \\
\text { Agree }\end{array}$ & $\mathbf{N} / \mathbf{A}^{*}$ \\
\hline & & 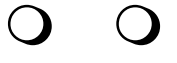 & \\
\hline $\begin{array}{l}\text { When I share knowledge with my employees, } \\
\text { I believe that my future requests for knowledge will } \\
\text { be answered by them }\end{array}$ & & & \\
\hline $\begin{array}{l}\text { Within my team, employees have reciprocal faith } \\
\text { in the behaviors and intentions of co-workers }\end{array}$ & & & \\
\hline Within my team all the employees are equal & & & \\
\hline $\begin{array}{l}\text { My organization uses technology infrastructure } \\
\text { that allows employees to share knowledge with other } \\
\text { people inside the organization }\end{array}$ & & & \\
\hline My employees are friendly and helpful & & & \\
\hline I care about the well-being of my employees & & & \\
\hline $\begin{array}{l}\text { I am willing to give up personal needs for the good } \\
\text { of the team/organization }\end{array}$ & & & \\
\hline I have to work closely with others to do my job well & & & \\
\hline I encourage diversity in opinions & D & $\bigcirc$ & \\
\hline
\end{tabular}

*Not applicable 


\begin{tabular}{|c|c|c|c|}
\hline & $\begin{array}{l}\text { Strongly } \\
\text { Disagree }\end{array}$ & $\begin{array}{r}\text { Strongly } \\
\text { Agree }\end{array}$ & $\mathbf{N} / \mathbf{A}^{*}$ \\
\hline \multicolumn{4}{|l|}{ I enjoy helping others by sharing my knowledge } \\
\hline \multicolumn{4}{|l|}{$\begin{array}{l}\text { I encourage a high participation in sharing } \\
\text { knowledge and ideas among employees }\end{array}$} \\
\hline \multicolumn{4}{|l|}{$\begin{array}{l}\text { In the organization employees make extensive } \\
\text { use of the electronic storage (such as databases } \\
\text { and data warehouses) to access corporate } \\
\text { knowledge }\end{array}$} \\
\hline \multicolumn{4}{|l|}{$\begin{array}{l}\text { I respect the customs and beliefs of } \\
\text { my employees }\end{array}$} \\
\hline \multicolumn{4}{|l|}{$\begin{array}{l}\text { I always put the interest of the whole } \\
\text { team before my own interest }\end{array}$} \\
\hline \multicolumn{4}{|l|}{ I have confidence and trust in the team } \\
\hline $\begin{array}{l}\text { Different ethnic groups work in harmony } \\
\text { within the organization }\end{array}$ & 0 & 0 & \\
\hline
\end{tabular}

*Not applicable

\begin{tabular}{|c|c|c|c|}
\hline & $\begin{array}{l}\text { Strongly } \\
\text { Disagree }\end{array}$ & $\begin{array}{r}\text { Strongly } \\
\text { Agree }\end{array}$ & $\mathbf{N} / \mathbf{A}^{*}$ \\
\hline I respect the religion of my employees & & & D \\
\hline $\begin{array}{l}\text { I see myself as an active listener towards } \\
\text { my employees }\end{array}$ & & & D \\
\hline $\begin{array}{l}\text { A crisis in the team will always be solved } \\
\text { in a harmonious way }\end{array}$ & O & & D \\
\hline $\begin{array}{l}\text { There is open communication in } \\
\text { the organization }\end{array}$ & & & D \\
\hline $\begin{array}{l}\text { All opinions have a fair hearing and } \\
\text { consideration within the team }\end{array}$ & & & D \\
\hline I take the time to greet my employees & O & D & $\cap$ \\
\hline $\begin{array}{l}\text { The organization provides all employees } \\
\text { open access to all information }\end{array}$ & O & O & O \\
\hline
\end{tabular}




\begin{tabular}{|c|c|c|c|}
\hline & $\begin{array}{l}\text { Strongly } \\
\text { Disagree }\end{array}$ & $\begin{array}{r}\text { Strongly } \\
\text { Agree }\end{array}$ & $\mathbf{N} / \mathbf{A}^{*}$ \\
\hline \multicolumn{4}{|l|}{ I value sharing what I have with my family } \\
\hline I provide equal opportunities to all within my team & O & O & O \\
\hline $\begin{array}{l}\text { I am confident in my ability to provide knowledge } \\
\text { that others in the organization find valuable }\end{array}$ & & & \\
\hline
\end{tabular}

*Not applicable

\begin{tabular}{|c|c|c|c|}
\hline \multirow[b]{2}{*}{$\begin{array}{l}\text { I view employee training as an investment rathe } \\
\text { than an expense }\end{array}$} & $\begin{array}{l}\text { Strongly } \\
\text { Disagree }\end{array}$ & $\begin{array}{r}\text { Strongly } \\
\text { Agree }\end{array}$ & \multirow{2}{*}{$\frac{\mathrm{N} / \mathbf{A}^{*}}{\mathrm{O}}$} \\
\hline & $\bigcirc$ & 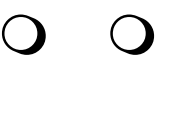 & \\
\hline $\begin{array}{l}\text { I receive increased promotion opportunities in } \\
\text { return for my knowledge sharing }\end{array}$ & $\bigcirc$ & D & \\
\hline $\begin{array}{l}\text { Top management provides a clear organizatior } \\
\text { vision and goals to employees }\end{array}$ & ) & D & \\
\hline Long discussions take place in team meetings & & & \\
\hline $\begin{array}{l}\text { My employees are people I inform about my } \\
\text { personal life }\end{array}$ & O & D & D \\
\hline I encourage dialogue during meetings & $\bigcirc$ & O & ) \\
\hline $\begin{array}{l}\text { In the organization ceremonies and personnel } \\
\text { parties are organized }\end{array}$ & O & O & 0 \\
\hline
\end{tabular}

*Not applicable

\begin{tabular}{|c|c|c|c|}
\hline & $\begin{array}{l}\text { Strongly } \\
\text { Disagree }\end{array}$ & $\begin{array}{r}\text { Strongly } \\
\text { Agree }\end{array}$ & $\mathbf{N} / \mathbf{A}^{*}$ \\
\hline $\begin{array}{l}\text { In the organization employees use knowledge } \\
\text { networks (e-mail, intranet, etc.) to communicate } \\
\text { with co-workers }\end{array}$ & 0 & 0 & D \\
\hline $\begin{array}{l}\text { Encouraging knowledge sharing with co-workers } \\
\text { is important component of my policy }\end{array}$ & 0 & 0 & 0 \\
\hline
\end{tabular}




\begin{tabular}{|c|c|c|c|}
\hline \multirow[b]{2}{*}{$\begin{array}{l}\text { I have the well-being of my employees as } \\
\text { a major objective }\end{array}$} & $\begin{array}{l}\text { Strongly } \\
\text { Disagree }\end{array}$ & $\begin{array}{r}\text { Strongly } \\
\text { Agree }\end{array}$ & $\mathbf{N} / \mathbf{A}^{*}$ \\
\hline & & ) & O \\
\hline $\begin{array}{l}\text { When a co-worker gets promotion and } \\
\text { I am not, I am happy for him/her }\end{array}$ & & 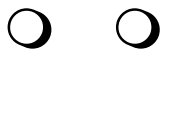 & \\
\hline $\begin{array}{l}\text { My employees and I get together outside } \\
\text { of work time }\end{array}$ & 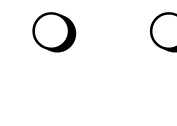 & 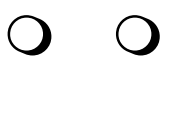 & \\
\hline I feel I am really a part of the team & & ) & \\
\hline The employees and I are like a family & & & \\
\hline $\begin{array}{l}\text { I encourage my team to suggest ideas for new } \\
\text { opportunities }\end{array}$ & & D & \\
\hline $\begin{array}{l}\text { I have the freedom to take my own approach } \\
\text { in my work }\end{array}$ & & & \\
\hline I have the right to say no to the team & & & \\
\hline I enjoy to work as a part of a team & & O & \\
\hline $\begin{array}{l}\text { My family is always welcome to visit } \\
\text { the organization }\end{array}$ & & & \\
\hline $\begin{array}{l}\text { When I share my knowledge with employees the } \\
\text { people I work with respect me }\end{array}$ & & & \\
\hline
\end{tabular}

*Not applicable 


\section{APPENDIX II: CRONBACH'S ALPHA}

Table 1. Cronbach's Alpha for Humanness and Knowledge Sharing Dimensions in Malaysia

\begin{tabular}{lcc}
\hline & Cronbach's Alpha & Nr. of Items \\
\cline { 2 - 3 } Humannes & 0.947 & 32 \\
Solidarity & 0.724 & 7 \\
Survival & 0.857 & 8 \\
Compassion & 0.819 & 8 \\
Respect \& Dignity & 0.819 & 10 \\
Knowledge sharing & 0.879 & 14 \\
Corporate Culture \& Leadership & 0.790 & 7 \\
Employee motivation & 0.750 & 3 \\
Information Technology & 0.674 & 3 \\
\hline
\end{tabular}

Table 2. Cronbach's Alpha for Humanness and Knowledge Sharing Dimensions in Tanzania

$\begin{array}{lrr}\text { Humanness } & 0.916 & 33 \\ \text { Solidarity } & 0.705 & 8 \\ \text { Survival } & 0.785 & 7 \\ \text { Compassion } & 0.726 & 8 \\ \text { Respect \& Dignity } & 0.891 & 10 \\ \text { Knowledge sharing } & 0.859 & 15 \\ \text { Corporate Culture \& Leadership } & 0.859 & 4 \\ \text { Employee Motivation } & 0.639 & 8 \\ \text { Information Technology } & 0.762 & 3\end{array}$




\section{APPENDIX III: PEARSON CORRELTATION}

Table 3. Correlations Humanness and Knowledge Sharing Dimensions

\begin{tabular}{llc}
\hline & & \multicolumn{1}{c}{ Humannes } \\
\cline { 3 - 3 } KnowledgeSharing & PearsonCorrelation & $0.841^{* *}$ \\
Corporate Culture and Leadership & PearsonCorrelation & $0.844^{* *}$ \\
Employee Motivation & PearsonCorrelation & $0.793^{* *}$ \\
InformationTechnology & PearsonCorrelation & $0.560^{* *}$ \\
\hline
\end{tabular}

**Correlation is significant at the 0.01 level (2-tailed)

All correlations have a significance of 0.00

$\mathrm{N}=214$.

\section{APPENDIX IV. KNOWLEDGE SHARING}

The study by Lin, Lee and Wang (2009) uses four dimensions. However, Scholtens (2011) found that the dimensions corporate culture and leadership \& management are too similar and need to be clustered together.

Corporate Culture \& Leadership According to the study of Lin, Lee and Wang (2009) entities need a social-oriented organizational climate to encourage knowledge sharing among employees. Social networks or informal networks within organizations influence knowledge sharing between employees. According to O'Dell and Grayson (1998) both formal and informal relationships and contacts between employees are important for the sharing process within organizations. Trust is important for managers to share their knowledge with others. Trust is one of the main aspects of the humanness dimensions because without trust there is no solidarity, survival, compassion or respect \& dignity.

Employee Motivation

Personal benefits are an important motivation for employees. To share knowledge with others, individuals need certainty that others will be worth the effort and that their expectations of receiving something of value in return are correct (Nahapiet and Ghoshal 1998). These 'private 
APPENDIX IV (Continued)

Information Technology rewards' accrue more likely to individuals who participate actively in the sharing process and are willing to help others (von Hippen and von Krogh, 2003). Secondly, the reputation of employees is a factor in their motivation. According to the social exchange theory (Blau 1964) 'individuals engage in social interaction and expect social rewards such as approval, status and respect'. Therefore, it is expected that individuals actively participate in the perception to enhance his or her personal reputation in an established network.

The final dimension refers to modern technology, which becomes more important with the development of Internet and information technology (IT). Moreover, earlier knowledge management research has indicated that IT can be seen as an important facilitator of knowledge sharing, which happens through the use of Internet, intranet, software agents, knowledge bases, and communities of practices (Song 2002). The use of Internet and IT systems make it possible to share information quick to departments all over the world and to a large number of individuals (Powell et al. 1996).

\section{APPENDIX V. HUMANNESS DIMENSIONS}

\section{Solidarity}

Survival
The dimension of solidarity is about the accomplishment of difficult tasks collectively. "The hallmark of the African philosophy is about being a good community member' writes Mbigi is his paper (2005b). Tutu (1999) explains that the solidarity of a person is the essence of being human. When a person is truly humanness this means he/she is generous, hospitable, friendly, caring, compassionate and share what they have. The persons within a community are inextricably bound to each other and appertain in a bundle of life.

This dimension has some overlap with the aforementioned concept of solidarity and therefore the two are closely related. To survive poverty, wars and political instability, 
APPENDIX IV (Continued)

\section{Compassion}

\section{Respect \& dignity}

Africans are dependent on each other. Therefore they need to share their resources and strengths to protect the community.Identically to solidarity, the dimension survival is about sacrifices individuals need to take for the sake of the community or team. According to Magaliso (2001) this kind of survival result in some sort of kinship in organizations. Family members help each other to find jobs, but it is shown as well between people who graduated from the same university.

As compassion is about understanding the problems of others and feel the urge to help them. Magaliso (2001) states that one should treat others as members of their own family which is done by compassion, kindness and humility. To reach out to help others and feel compassionate towards their problems is the foundation on which relationships and friendships are based (Pooven et al. 2006). Within organization and team formations, a shared vision is important to increase the ability of teams to perform successful.

Within the humanness management style people sense that they are treated with respect and dignity. These people show greater commitment to the goals of an organization and therefore work harder to achieve them (Mangaliso 2001). As is stated before, the utility of finding a decision which is supported by all members of a team or organization is more important than finding the best decision. Furthermore, there is a deep respect for the elderly, authority and others who fulfill their obligations for the sake of the community (Mbigi 1997). 